\title{
Selfie-Mania Influence on Adolescent Self-Esteem
}

Flora Zeqaj Lamçja

\author{
"A. Xhuvani" University of Elbasan, Albania, Faculty of Medical Technical Sciences
}

PhD Cand. European University of Tirana

\begin{abstract}
Our society new where technology has touched every cell of it is becoming even more virtually from where fashion is Selfie therefore be shooting themselves, a modern trend which has involved the whole society on the plates as Instagram, Facebook, Twitter, Snapchat, etc. Art selfie is one that many people have practiced and perfected over the years, but knowing what relationship they have with this new generation of virtual relationship remains a difficult task as important as well. This study aims to explore the selfie as a reflection of low selfesteem because the mania for photographing herself, is a pathology of the syndrome in search of a stable personality. Target group of this study were middle school students "Dhaskal Todri" in Elbasan, where 100 participants aged 16-18 years from where 39 participants were males and 61 females. They were asked to fill the Rosenberg Self-Assessment Inventory (Rosenberg Self-Esteem Inventory, 1965) within ethical standards. After analysis of the data showed a positive correlation between connectivity Selfie - Self-Esteem which holds that studies to date have shown that there is a connection between the selfie mania and self-esteem. Out of the sample obtained in this study show that individuals are looking for a better image of themselves as self images contradict the image of a secure existence, through fixing a few moments as a symbol of an attempt to establish an identity consistent, full realized. The pathology of this syndrome is the search for a stable personality. Of course, we are talking about the first research on this phenomenon should probably be more careful diagnostic categorization and labeling.
\end{abstract}

Keywords: Self-esteem, selfie- mania, adolescent

\section{Introduction}

\section{Overview of the problem of study}

Each of us in one way or another is fascinated by the pictures on the fact that consists of a tow universal and this is explained very simply: just a shot we all encourage curiosity to see how we have come despite the reactions of each of us. They are subjective and are related to image internal, mental scheme that we perceived ourselves having to do with how we see ourselves and how we want others to see us. Photography is seen as a powerful means of expression, as a symbolic language to express what can not be said in words, and as a stimulator of emotions and behaviors about which often are not aware of. The first to have captured value therapeutic photography field of mental health was Hugh Diamond (1856), amateur photographer and psychiatrist at the Psychiatric Hospital Surrey County Lunatic Asylum, first using photographs of his patients as a diagnostic tool for identifying mental disorder.

Oxford dictionary (2013) defined this term as, "A photograph that one has taken of oneself, typically one taken with a smartphone or webcam and shared via social media". But before the rise of this selfie concept, smart phones or social media, the thought of taking self portraits was existed among people with using self-timers on the cameras. But the idea behind the selfie meant to be different than using a self timer, and also it should not take a longer snapping time process as self timer. Most importantly to be a selfie, photograph should be captured with a camera held at arm's length or focused at a mirror. The other version of the selfie is group selfie, where the subject of the selfie is joined or crowded or at least with one other person. It is also gaining wide popularity in the selfie culture. And now the tendency is called them as 'usie', the 'self' replaced by a collective 'us'. Anyway the whole concept is; wherever you are, whatever you are doing, with whom you 
are with, taking a snapshot of yourself to express it just as quick as you can. History Before coming into photography, the earliest selfie looking painting was done by Parmigianino way back in 1524, and it was named as "Self-portrait in a Convex Mirror". In the painting, it portrays the artist himself distorted by a convex mirror which made it exactly look like a selfie. The very first self photograph or somewhat called selfie was taken by Robert Cornelius, an amateur chemist and photography enthusiast, in way back 1839, very early days of photography explorations, experimentations and inventions. Because of the slow capturing process at that time in camera's, after setting up the camera he was able to run back and sit in front of the camera decently without peeping into it. After 1900 s mirror selfie technique was widely being used even it was not termed as selfie at that time. The first teenager who took a selfie was identified as Russian Grand Duchess Anastasia Nikolaevna from the last Tsar family in 1914 when she was 13 years old. She used the mirror technique to capture the photo and says about that experience like this. The 'Selfie Effect' in regular society picture of myself looking at the mirror. It was very hard as my hands were trembling. "

Selfie and Regular Life The practical usage of this term was not being widely utilized until 2010 , and come into to use in day to day life just from past couple of years. The main reason behind this was the easy access to smart phones gradually among the population (Dormann, C. ; Fay, D. ; Zapf, D. ; Frese, M. (2006). Nowadays it is customary to include a built in camera on every smart phone device. And sometimes it really confuses whether the phone is having a camera option or camera is having a phone option because of the high tech photography technologies it incorporates. And this technology ensured that selfies are more and more easier to produce and share on the web, making even regular people to do photography not only just pros. It was even become trendier after the front facing camera designs were integrated into the smart phones. When the social media sites become apps for the smart phones and introduction of mobile photo sharing apps such like Instagram with incorporated photo retouching features, selfie becomes more and more familiar obsession among the society, specifically among the young generation. Because this immediate photo sharing technology supports the person to say without uttering a word; where he is now, what he is doing now, what he looks like now and most significantly to state "Hello, this is me". According to WebSta Instagram Web Viewer, usage of hashtag '\#selfie' on Instagram retrieves 180, 026, 033 posts and on 14th place over top 100 tags in 2014 October.

Sociological Effects Selfie (Olsen, J. M. ; Breckler, S. J. ; Wiggins, E. C. (2008) is perhaps tending to be a greater interest for social scientists. With thorough analysis it is evident that, this becoming more fashionable predominant trend among young generation. In a more detail level it is apparent that teenage girls are more tend to capture their selfie faces when a new hairstyle, makeup or facial going on with them. Taking a selfie when on a special occasion, or else before the participation of the event, becoming a typical scenario among teen girl culture. Most notable selfies have odd angles, kissy faces or looking in a direction that is not towards the camera. In particularly mirror selfies are their habitual behavior to show off when a new outfit wears on. So it is clear that teen girl customary is still not changed from the time period of last Tsar family as we mentioned about 13 years old Anastasia before.

The trend of shooting ourselves is back in vogue, also tend to Albanian teenagers to stop this study will specifically exploring the selfie as a reflection of low self-esteem and narcissism. In fact, traditional ignores narcissism contact with others, the person itself creates an exaggerated self-image. In Greek mythology narcissus so much in love with his own image reflected in the water that spellbound with this love, lost and falling into the river where self - reflected. Network social networks can be conceived as a large mirror narcisizte, to tell others who you are as valid and able to communicate those aspects of yourself emotionally and often unrealistic, avoiding the difficulties of coping through direct contact. So anyway avoids individual real contact, directly with another, and seeking to "sell" themselves another, more perfect. It seems that social networking presents an overview and a mask at the same time. Studies show that spending more time on Facebook by posting vetëportrete narcisizte trend is increasing worldwide.

The 'Selfie Effect' in regular society it was identified that he was diagnosed with body dysmorphic disorder (BDD), also known as body dysmorphia or dysmorphic syndrome. A mental illness that causes one to sufferer and spend a lot of time worrying about their appearances. After the medical therapies, his thoughts echoed that, this selfie taking addiction was like drugs, alcohol or gambling, which is quickly spiral out of control.

If you ask a link between Selfie- Syndrome and psychopathology, this leads to criteria of addiction, mood disordered situations, obsessive thoughts, obsessive - compulsive disorder. Certainly seeing this phenomenon in this context, we are talking about research money should probably be more careful diagnostic classification and labeling. 


\section{Selfie-Mania influence on adolescent self-esteem}

In the minds of individuals who like self-portraits publication there is something wrong. This is the opinion of some researchers that American Psychiatric Association in a study recently pointed out that this is explained by a wish ill to make files yourself and then you publish them on the web and this serves to compensate for the lack of confidence. The first indicator that pushes the individual to selfie is a strong will of the person to tell the world: "I'm here and I'm doing this. " Studies to date have shown that there is a connection between the selfie mania and self-esteem (Mruk, C. (2006). People who make picture yourself are looking for a good image for themselves. Young people, especially teenagers, do not feel you realize and it causes a vague idea about yourself. The cause of the first is a problem of identity as opposed vetëportretet image of a precarious existence, through fixing a few moments as a symbol of an attempt to establish an identity consistent, complete and successful. Allegations of social context require an ideal person and it brings uncertainty, which pushes toward creating a perfect image for yourself seeking to stop now. The photos are as a means to demonstrate the existence of a person. The pathology of this syndrome is the search for a stable personality. Individuals have weak personality and constantly seek confirmation through like-ve or comments to understand who they are and they're worth. Art selfie is one that many people have practiced and perfected over the years, where today more than 31 million people worldwide are constantly posting pictures of themselves, so that it has turned into a desire -obesesive where already under a recent study by the Pew Research Center shows that $91 \%$ of teenagers post their images continuously in social media so compulsive. According to Pamela Rutledge Ph. D, Dean of the Faculty of Media Psychology program at the Massachusetts School is a post selfies empowering act for an image of himself alienated from where Samantha, a 19-year-old girl claimed that why it was posting so compulsive photo of themselves on social media was the satisfaction he received when taking Like and positive reviews for her image. According Dr. Weber girls who repeatedly make selfies struggle with low self-esteem. Thinking of others has been a part of identity development for more than a century of by Andrea Letamendi Ph. D, a doctor of psychology at UCLA, concluded that by posting pictures so compulsive individuals reflect low self-esteem and strengthen the influence of others on their lives. Dr. Letamendi claims that individuals who tend to have low self-esteem and are depressed are more likely to engage in making self-portraits.

Social networks (Johnson E. A. ; O'Brien K. A. (2013) have changed the way we communicate and keep in touch with friends all over the world, but also are undeniable and, unintended consequences arising from their excessive use. Well, according to the researchers, the excessive use of social networks can be associated with several psychiatric disorders, from where, according to studies conducted in 2010 at the University of York which examine the social network connection self concluded that users of social networks They tend to have narcissistic personality and low self-esteem. According to a search of Amanda Forrest of the University of California and Joanne Wood University of Waterloo, published in Psychological Science, people with low self-esteem tend, inter alia, to post pictures: they tend to criticize those who should be their friends and highlight the negative aspects.

When we do we look very attractive Selfie in most cases due to the effects of technology. Even doctors (Marsh, H. W. (1990) give Selfie alarm that reflects the lack of confidence and that many individuals are inclined towards plastic surgery according to the findings of a study that took into account the 2700 cases treated by surgeons specializing amarikanë interventions ot facial plastic surgery. Mania to photograph themselves, is a pathology of the syndrome in search of a stable personality.

Self-esteem (Branden, N. (1969) is a very broad term for how good or bad we feel about ourselves, and it can generally vary as per time. For example, if you fail a test it may be upsetting, but ultimately a grade doesn't determine who you are. People who have low self-esteem commonly have a very pessimistic outlook and are often quite self-critical, withdrawn socially, and are overwhelmed with feelings of inferiority. A person with low self-esteem may them feel better. So they rather don't focus on more important ways of changing their negative self-place importance on their looks, thinking that taking and posting selfies will help image such as self-acceptance, self-compassion, and self-respect which is undesirable.

This study is an innovation for our society in the context of clinical studies.

\section{Definition of terms and their operationalization}

Self -esteem: In sociology and psychology, self-esteem reflects a person's overall subjective emotional evaluation of his or her own worth. It is a judgment of oneself as well as an attitude toward the self. Self-esteem encompasses beliefs about oneself, (for example, "I am competent", "I am worthy"), as well as emotional states, such as triumph, despair, pride, 
and shame. Smith and Mackie (2007) defined it by saying "The self-concept is what we think about the self; self-esteem, is the positive or negative evaluations of the self, as in how we feel about it. Self-esteem is attractive as a social psychological construct because researchers have conceptualized it as an influential predictor of certain outcomes, such as academic achievement, happiness, satisfaction in marriage and relationships, and criminal behaviour. Self-esteem can apply specifically to a particular dimension (for example, "I believe I am a good writer and feel happy about that") or a global extent (for example, "I believe I am a bad person, and feel bad about myself in general"). Psychologists usually regard selfesteem as an enduring personality characteristic ("trait" self-esteem), though normal, short-term variations ("state" selfesteem) also exist. Synonyms or near-synonyms of self-esteem include: self-worth, self-regard, self-respect, and selfintegrity.

Selfie- mania: Selfies are photos of a person which usually consist of up-close angles of a person's face. The term selfie has become so immersed in our daily use vocabularies now, that not only has it officially entered into the Oxford English Dictionary, but "selfie" was Oxford English Dictionary's Word of the Year for 2013. It is described as when an individual holds a camera or smartphone at arm's length and takes a picture of their face. But honestly, some of these may come across as awkward. There tend to be various poses including the discrete pouting, the 'duck' face or lips pose, the funnytrying-to-be-cute face, etc.

Adolescence: Adolescence describes the teenage years between 13 and 19 and can be considered the transitional stage from childhood to adulthood. However, the physical and psychological changes that occur in adolescence can start earlier, during the preteen or "tween" years (ages 9 through 12). Adolescence can be a time of both disorientation and discovery. The transitional period can bring up issues of independence and self-identity; many adolescents and their peers face tough choices regarding schoolwork, sexuality, drugs, alcohol, and social life. Peer groups, romantic interests, and external appearance tend to naturally increase in importance for some time during a teen's journey toward adulthood.

\section{Methodology:}

\section{The purpose and objectives of research:}

To explore the correlation relationship between selfie mania and self- esteem.

\section{This study is an innovation for our society in the context of clinical studies.}

\section{The focus of research}

This research will be focused on adolescence:

By involving in the sample only the adolescents $16-18$ years old .

\section{Sample}

Target group of this study were middle school students "Dhaskal Todri" in Elbasan, where 100 participants aged 16-18 years from where 39 participants were males and 61 females.

\section{Study measuring instruments}

Instruments used for evaluation Self esteem in adolescents selected for this quantitative study are:

\section{Rosenberg, inventory}

Self-esteem is typically assessed using self-report inventories. One of the most widely used instruments, the RSES (Rosenberg, 1965) is a 10-item self-esteem scale scores that requires participants to indicate their level of agreement with a series of statements about themselves.

\section{Results}

After analysis of the data showed a positive correlation (tab. I) between connectivity Selfie - Self-Esteem which holds that studies to date have shown that there is a connection between the selfie mania and self-esteem. Out of the sample obtained in this study show that individuals are looking for a better image of themselves as self images contradict the image of a secure existence, through fixing a few moments as a symbol of an attempt to establish an identity consistent, full realized. 
The pathology of this syndrome is the search for a stable personality. Of course we are talking about the first research on this phenomenon should probably be more careful diagnostic categorization and labeling.

\section{Pearson Correlation Table 1. 3}

\begin{tabular}{|l|l|l|l|}
\hline Question & Valid & Missing & Pearson Correlation \\
\hline 1. On the whole, I am satisfied with myself. & 65 & 0 & 1.00 \\
\hline 2. At times I think I am no good at all. & 65 & 0 & $.714^{* *}$ \\
\hline 3. I feel that I have a number of good qualities. & 65 & 0 & 1.00 \\
\hline 4. I feel I do not have much to be proud of. & 65 & 0 & $.308^{*}$ \\
\hline 5. I am able to do things as well as most other people. & 65 & 0 & 1.00 \\
\hline 6. I certainly feel useless at times. & 65 & 0 & $.514^{* *}$ \\
\hline $\begin{array}{l}\text { 7. I feel that I'm a person of worth, at least on an equal } \\
\text { plane with others. }\end{array}$ & 65 & 0 & $.340^{* *}$ \\
\hline 8. I wish I could have more respect for myself. & 65 & 0 & $.592^{* *}$ \\
\hline 9. All in all, I am inclined to feel that I am a failure. & 65 & 0 & $.971^{* *}$ \\
\hline 10. I take a positive attitude toward myself. & 65 & 0 & .243 \\
\hline
\end{tabular}

${ }^{* *}$. Correlation is significant at the 0.01 level (2-tailed)

*. Correlation is significant at the 0.05 level (2-tailed)

I think "True self-esteem comes from connecting with and serving others".

\section{References}

[1] Branden, N. (1969). The Psychology of Self-Esteem. New York: Bantam.

[2] Marsh, H. W. (1990). "Causal ordering of academic self-concept and academic achievement: A multiwave, longitudinal path analysis. ". Journal of Educational Psychology. 82 (4): 646-656. doi:10. 1037/0022-0663. 82. 4. 646

[3] Baumeister, R. F. ; Campbell, J. D. ; Krueger, J. I. ; Vohs, K. D. (2003). "Does High Self-Esteem Cause Better Performance, Interpersonal Success, Happiness, or Healthier Lifestyles?". Psychological Science in the Public Interest. 4 (1): 1-44. doi:10. 1111/1529-1006. 01431. ISSN 1529-1006

[4] Dormann, C. ; Fay, D. ; Zapf, D. ; Frese, M. (2006). "A state-trait analysis of job satisfaction: On the effect of core self-evaluations". Applied Psychology: An International Review. 55 (1): 27-51. doi:10. 1111/j. 1464-0597. 2006. 00227.

[5] Olsen, J. M. ; Breckler, S. J. ; Wiggins, E. C. (2008). Social Psychology Alive (First Canadian ed. ). Toronto: Thomson Nelson. ISBN 978-0-17-622452-3.

[6] Mruk, C. (2006). Self-Esteem research, theory, and practice: Toward a positive psychology of self-esteem (3rd ed. ). New York: Springer. 
[7] Johnson E. A. ; O'Brien K. A. (2013). "Self-compassion soothes the savage ego-threat system: Effects on negative affect, shame, rumination, \& depressive symptoms". Journal of Social and Clinical Psychology. 32 (9): 939-963.

[8] Oxford Dictionaries. The Oxford Dictionaries Word of the Year 2013 is.... OxfordWords blog. [Online]November 18, 2013. http://blog. oxforddictionaries. com/2013/11/word-of- the-year-2013-winner/

[9] Atchison, Bob. Letters of Grand Duchess Anastasia. Alexander Palace Time Machine. [Online] [Cited October 11, 2014. ] http://www. alexanderpalace. org/palace/adiaries. html. :

[10] Sifferlin, Alexandra. Why Selfies Matter. Time. [Online] September 6, 2013. [Cited: October 22, 2014. ] http://healthland. time. com/2013/09/06/why- selfies-matter 